\title{
Efficacy of Seed Treatment with Fungicides and Bioagent on Germination and Percent Disease Incidence of Chickpea Wet Root Rot Rhizoctonia solani (Kuhn) (Sick soil/ pot culture)
}

\author{
P.K. Ambhore ${ }^{1 *}$, P.B. Khaire ${ }^{2}$ and R.S. Desai ${ }^{3}$ \\ ${ }^{1}$ Department of Plant Pathology SDMVM's College of Agriculture Georai Tanda, Paithan \\ Road, Aurangabad (M.S.)-431001, India \\ ${ }^{2}$ College of Agriculture Naigaon (Bz.), Nanded, (M.S), India \\ ${ }^{3}$ Department of Plant Biotechnology SDMVM's College of Biotechnology Georai Tanda, \\ Paithan Road, Aurangabad (M.S.)-431001, India \\ *Corresponding author
}

\section{A B S T R A C T}

\section{Keywords}

Rhizoctonia solani,

Chickpea, Fungicides,

Biocontrol agents

Article Info

Accepted:

15 September 2018

Available Online:

10 October 2018
Four fungicides and two bioagents of different groups evaluated for seed treatmentagainst Rhizoctonia solani, Carbendazim + Mancozeb (88.54\%), Carbendazim (71.49\%), were proved to be most effective in inhibiting the growth of the fungus. Among the bio-agents screened, Trichoderma viride $(50.23 \%)$ was most effective in restricting the growth of Rhizoctonia solani where as Metalaxy $(65.91 \%)$ was proved least effective.

\section{Introduction}

It contains 21.1 per cent protein, 61.5 per cent carbohydrates, 4.55 per cent fat besides rich in $\mathrm{Ca}, \mathrm{Fe}$ and Niacin. Its leaves secrete malic acid (90-95 percent) cum oxalic acid (5 to 10 percent), which has medicinal importance against stomach ache, intestinal disorder and blood purification.

In Indian context, chickpea is an important Rabi pulse crop, both in acreage and production next to wheat. It is the third major pulse crop after grass pea and lentil (Islam et al., 1981). Chickpea is the most important one being rich source of protein (21\%), carbohydrate $(61.51 \%)$, fat $(4.5 \%)$ and vitamin C. Fifty different pathogens have so far been reported on chickpea (Nene et al., 1989) In a pot culture study, Trichoderma was very effective against seedling mortality of chickpea caused by root rot (Khan 2003). Trichoderma harzianum has been found as an effective biocontrol agent of soil and seed borne plant pathogenic fungi (Begum et al., 1999; Chowdhury et al., 2000, Akter, 2001). 
A large number of diseases have been reported on chickpea, right from early seedling stage up to maturity, of which wilt (Fusarium oxysporum f. sp. ciceri), dry root rot (Rhizoctonia bataticola), wet orot rot (Rhizoctonia solani), stem rot (Sclerotiana sclerotiorum), blight (Aschochyta rabie), stunt and mosaic (viral diseases) are important. Amongst all these diseases, wet root rot caused by Rhizoctonia solani f.sp. ciceri Kuhn.

The pathogen caused significant reduction in plant population having wide host range (Aycock, 1966).

\section{Materials and Methods}

\section{Effect of seed treatment with fungicides and bioagents against wet root rot chickpea (Pot culture)}

The experiment was conducted to find out an effective antagonistic treatment which enhance germination, shoot length, root length and minimizing mortality of seedling. Polythene bags were filled with inoculated soil. The soil was inoculated with test fungus $R$. solani grown on chickpea straw medium. Seeds of chickpea variety JG 62 were sown with different treatments viz., seed treatment, soil application were sown in each bag. Untreated seeds sown in the infected soil with R.solani as a control. Three replications were maintained. Observations on germination, pre and post emergence mortality were recorded.

\section{Seedling inoculation}

Sterilized soil was taken in polythene bags, surface sterilized JG 62 chickpea seeds were sown in polythene bags in net house. The test fungus inoculated on seven days old seedlings at collar region. Observation on the mortality of seedlings was recorded seven days after inoculation.

\section{Soil infestation}

The inoculum was thoroughly mixed in sterilized sand + soil (1:1)@ $100 \mathrm{~g} / 2 \mathrm{~kg}$ of soil. The sterilized soil mixed with inoculums multiplied on chickpea straw was placed in polythene bags. Chickpea seeds of JG 62 were surface sterilized with $0.1 \%$ sodium hypo chloride for one minute.

Ten seeds were placed in one polythene bag and three replications of the bags were maintained. These bags were kept in a net house. Proper isolation was maintained to avoid infection of other pathogens. Observations on germination, pre and post emergence mortality were recorded.

\section{Results and Discussion}

\section{Effect of seed treatment with fungicides, bioagents}

A total of four fungicides (two systemic and two combi-fungicides), two fungal bioagents (T. viride) and (T. harzianum) those found most effective against $R$. solani were taken for pot culture experiment during Rabi 2014. A seed treatment was undertaken in this experiment.

The results obtained on percentage seed germination, Pre Emergence Seed Rot (PESR), Post Emergence Seedling Mortality (PESM), per cent mortality and disease incidence reduction over control are presented.

Results revealed that all the treatments significantly influenced the percentage wet root rot disease incidence in chickpea $\mathrm{Cv}$. JG 62 during Rabi, 2014 season.

The disease was found to appear first about 20 days after challenge inoculation i.e. sick soil ( $R$. solani) on JG 62; which was later increased slightly up to seedling stage. 
Effect of fungicides, bioagents on pre emergence seed rot and post emergence seedling mortality caused by R. solani (Sick soil/ pot culture)

\begin{tabular}{|c|c|c|c|c|c|c|c|}
\hline \multirow[t]{2}{*}{ Tr. No. } & \multirow[t]{2}{*}{ Treatments } & \multirow[t]{2}{*}{ Rate } & \multirow{2}{*}{$\begin{array}{c}\text { Germination } \\
(\%)^{*}\end{array}$} & \multicolumn{2}{|c|}{ Seed Rot/Seedling Mortality (\%) } & \multirow{2}{*}{$\begin{array}{c}\text { Total Disease } \\
\text { incidence } \\
(\%)^{*}\end{array}$} & \multirow{2}{*}{$\begin{array}{l}\text { Total disease } \\
\text { reduction over } \\
\text { control }(\%) *\end{array}$} \\
\hline & & & & $\begin{array}{c}\text { Mean } \\
\operatorname{PESR}(\%)^{*}\end{array}$ & $\begin{array}{c}\text { Mean } \\
\text { PESM }(\%)^{*}\end{array}$ & & \\
\hline $\mathbf{T}_{1}$ & Carbendezim & $1.5 \mathrm{~g} / \mathrm{kg}$ & $91.6(73.25)$ & $8.3(16.73)$ & $10.6(19.05)$ & $18.9(25.81)$ & $71.49(44.18)$ \\
\hline $\mathbf{T}_{2}$ & $\begin{array}{c}\text { Carbendezim + } \\
\text { Mancozeb }\end{array}$ & $3 \mathrm{~g} / \mathrm{kg}$ & $97.0(80.10)$ & $3.0(98.79)$ & $\begin{array}{c}4.6 \\
(12.28)\end{array}$ & $07.6(15.87)$ & $88.54(62.25)$ \\
\hline$\overline{T_{3}}$ & Mancozeb & $3 \mathrm{~g} / \mathrm{kg}$ & $89.0(70.63)$ & $11.0(19.35)$ & $14.3(22.10)$ & $25.3(30.14)$ & $61.84(36.83)$ \\
\hline $\mathbf{T}_{4}$ & Metalaxyl & $3 \mathrm{~g} / \mathrm{kg}$ & $90.6(72.22)$ & $9.3(17.74)$ & $13.3(21.39)$ & $22.6(28.40)$ & $65.91(40.17)$ \\
\hline $\mathbf{T}_{\mathbf{5}}$ & T. viride & $10 \mathrm{~g} / \mathrm{kg}$ & $88.3(70.03)$ & $11.7(19.95)$ & $21.3(27.48)$ & $33.0(35.03)$ & $50.23(30.12)$ \\
\hline $\mathrm{T}_{6}$ & T. harzianum & $10 \mathrm{~g} / \mathrm{kg}$ & $90.0(71.57)$ & $10.0(18.41)$ & $19.3(26.06)$ & $29.3(32.76)$ & $55.81(34.12)$ \\
\hline \multirow[t]{3}{*}{$\mathbf{T}_{7}$} & Control & -- & $76.7(61.12)$ & $23.3(28.86)$ & $43.0(40.96)$ & $66.3(54.59)$ & $0.00(00.0)$ \\
\hline & \multicolumn{2}{|c|}{$\mathrm{SE} \pm$} & 0.7 & 0.75 & 1.11 & 1.45 & 1.19 \\
\hline & \multicolumn{2}{|c|}{$\mathrm{CD}$ at $1 \%$} & 2.4 & 2.24 & 3.31 & 4.30 & 3.53 \\
\hline
\end{tabular}

PESR: Post Emergence Seed Rot, PESM: Pre Emergence Seedling Mortality 


\section{Seed treatment with fungicides, Bioagents against chickpea wet root rot}

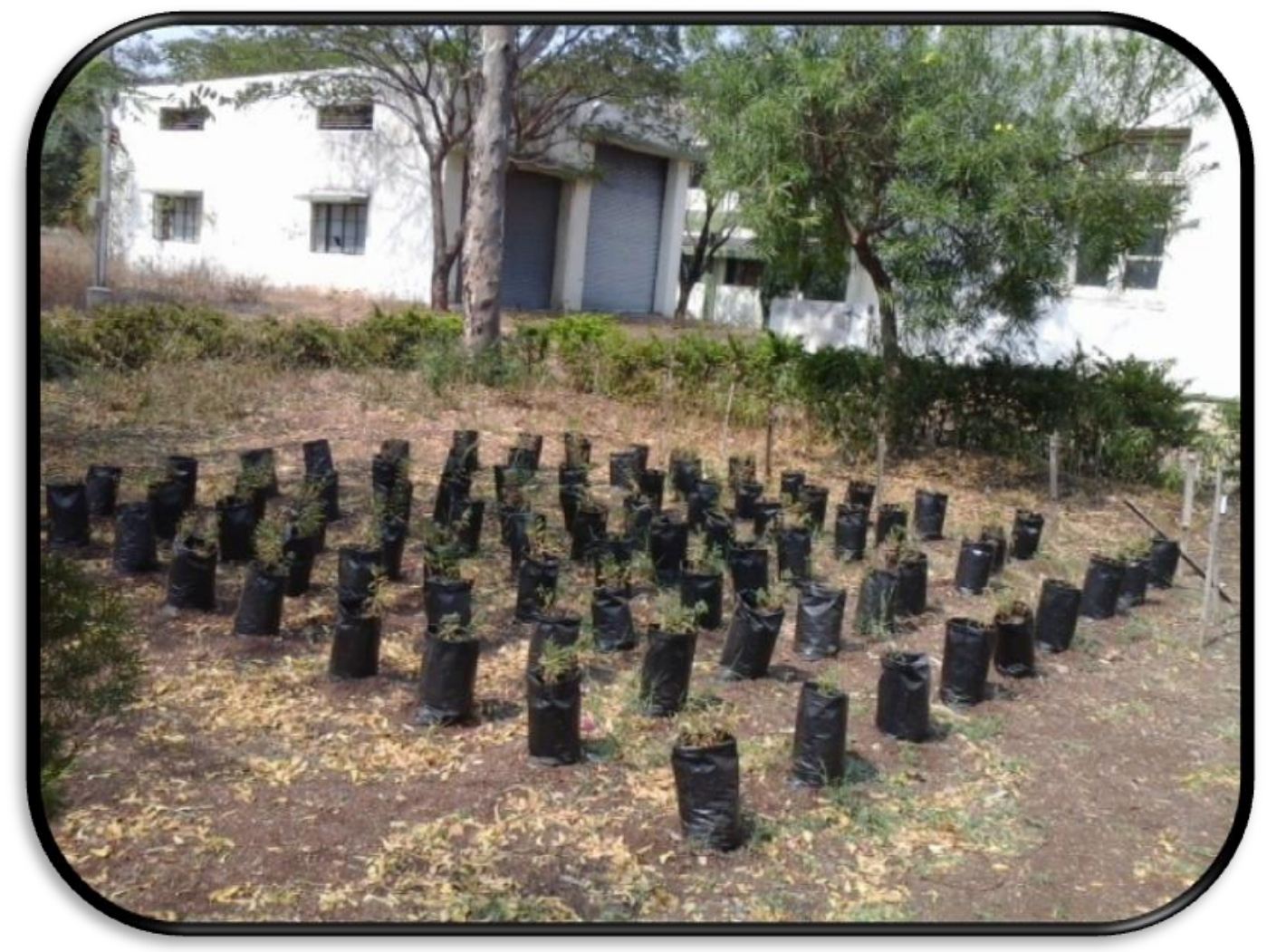

\section{Pre and post emergence mortality}

Results indicated that all the treatments significantly influenced both types of the mortalities (PESR and PESM) over untreated control.

The Pre Emergence Seed Rot (PESR) recorded with all the treatments was in the range of 3 to 19 per cent, as against untreated control $(23.3 \%)$. The superior seed treatments applied before sowing (in pot culture) viz., Carbendezim + Mancozeb, Carbendezim, were found with significantly least PESR of $(3 \%),(8.3 \%)$ and respectively. These were followed by treatments viz., T. harzianum (10 $\%)$, T. viride $(11.7 \%)$ However, untreated control showed maximum PESR $(23.3 \%)$.

The percentage post emergence seedling mortality recorded with all the treatments was in the range of 4.6 to $30.3 \%$ as against untreated control $(43.0 \%)$. However, the treatment viz., Carbendezim + Mancozeb, Carbendezim, Metalaxyl recorded significantly least PESM (4.6 \%), (10.6\%) and $(13.3 \%)$, respectively. These were followed by the treatments viz., T. harzianum (19.3 \%), T. viride (21.3\%). However, untreated control showed maximum PESM $(43.0 \%)$. All the treatments were significant over the untreated control.

Total wet root rot disease incidence of all the treatments was in the range of 7.6 to 49.3 per cent, as against (66.3) per cent untreated control. However, the treatment of Carbendezim + Mancozeb was found most effective with least average mortality $(7.6 \%)$. This was followed by the treatments viz., Carbendezim (18.9\%), Metalaxyl (22.6\%), Mancozeb (25.3\%), T. harzianum (29.3\%), T. viride $(33.0 \%)$. However, untreated control showed maximum mortality (66.3\%). All the 
treatments were significantly superior over the untreated control.

\section{Reduction in mortality}

The percentage reduction in PESR recorded with all the treatments was in range from 18.45 to 87.12 percent. However, the treatment Carbendezim+ Mancozeb $\quad$ (87.12 $\%)$, Carbendezim (64.38 \%) and Metalaxyl $(60.09 \%)$ were found most effective with significantly highest reduction in PESR i.e. 89.30, 75.35, 69.07 per cent in PESM respectively. These were followed by the treatment viz., T. harzianum (57.08 \%), T. viride $(49.79 \%)$.

The percentage reduction in post emergence seedling mortality (PESM) recorded with all the treatments were in the range of 29.53 to 89.30 per cent over untreated control. However, significantly highest reduction in Pre Emergence Seedling Mortality was recorded with the treatment of Carbendazim+ Mancozeb (89.30\%) followed by Carbendazim (75.35\%), Metalaxyl (69.07 $\%)$, Mancozeb (66.74 \%), T. harzianum (55.12\%), Trichoderma viride (50.47\%).

\section{References}

Akter, M. (2001). Biological control of seed and seedling disease of okra and cucurbits. M.S. Thesis, Department of Plant Pathology, Bangladesh Agricultural University, Mymensingh, Bangladesh.

Aycock. (1966). Stem rot and other disease caused by Sclerotium rolfsii. NC. Agric. Exp. 8th Tech: 174-202.

Begum, M. M., Rahman, M. A. and Hossain, I. (1999). Antagonistic effect Trichoderma harzianum on Sclerotium rolfsii in food legumes. Bangladesh $\mathrm{J}$. Bio Science, 7:81-88.

Chowdhury, M.S.M., Hossain I, Fakir GA, Aminuzzaman FM, Islam MR 2000: Tolerance of Trichoderma harzianum and Gliocladium viride to agrochemicals and their antagonistic effect on seed borne microflora of pigeon pea. Bangladesh. J. Seed Sci. Tech. 4(1\&2) 83-86.

Islam, M.Q., Sarker, A.T, Quader, M. and Begum, L. (1981) Status of Chickpea Improvement at BARI. In Proc. National Workshop on Pluses at Joydebpur. A.K. Kaul (Ed.) 1982. pp. 56-64.

Nene, Y. L. (1980). Diseases of chickpea. Proceedings of International Workshop on Chickpea Improvement, 28 February-2 March 1979, ICRISAT, Patancheru, A.P. India. 502 324. pp: 171-178.

\section{How to cite this article:}

Ambhore, P.K., P.B. Khaire and Desai, R.S. 2018. Efficacy of Seed Treatment with Fungicides and Bioagent on Germination and Percent Disease Incidence of Chickpea Wet Root Rot Rhizoctonia solani (Kuhn) (Sick soil/ pot culture). Int.J.Curr.Microbiol.App.Sci. 7(10): 19031907. doi: https://doi.org/10.20546/ijcmas.2018.710.219 